Канд. техн. наук А.В. Труфанова

\title{
ДО ПИТАННЯ ВИЗНАЧЕННЯ НАДІЙНОСТІ БУКСОВИХ ВУЗЛІВ ВАНТАЖНИХ ВАГОНІВ
}

\author{
Представив д-р техн. наук, професор О.В. Устенко
}

Постановка проблеми у загальному вигляді, іiї зв'язок 3 важливими науковими та практичними завданнями. Залізничний транспорт $\epsilon$ однією 3 найважливіших галузей народного господарства України. Гостра конкуренція між різними видами транспорту сприяє підвищенню якості транспортних послуг. Затримка вантажів у дорозі, яка викликана відмовою елементів конструкцій вагонів 3 подальшим відчепленням від поїзда, спричиняє суттєві економічні збитки залізницям.

Для забезпечення безпеки руху поїздів парк вантажних вагонів повинен мати високу надійність. У той же час вагон складається 3 великої кількості вузлів, технічний стан яких безпосередньо впливає на експлуатацію вантажних вагонів.

Важливим елементом ходових частин є буксові вузли. Багаторічний досвід експлуатації буксових підшипникових вузлів вантажних вагонів, що обладнані циліндричними роликовими підшипниками, навіть 3 чисельними модернізаціями показав, що вони не відповідають сучасним умовам експлуатації через недостатню надійність.

При розрахунку на міцність i надійність елементів конструкції буксових вузлів використовуються спрощені схеми, які не враховують ряд діючих чинників. Недосконалість існуючих методів розрахунку призвела до значних похибок при визначенні показників надійності буксових підшипникових вузлів і розбіжності 3 фактичними результатами експлуатації.

Аналіз останніх досліджень i публікацій. У дослідженнях професора О.М. Савчука [1] запропонована теорія i алгоритм розрахунку букси із урахуванням усіх деформацій усіх деталей та зазорів у з'єднаннях. Автором використовується скінченно-елементний підхід сумісно із загальним методом сил. Для букси вантажного вагона застосована плоска різнотовщинна розрахункова схема.

В дослідженнях [2] Ю.Д. Мельниченко використовував методику визначення напруженого стану корпусу букси та 
розподілення радіальних навантажень між роликами підшипника. Але така розрахункова схема не враховує всі особливості геометрії корпусу букс, податливість осі підшипника; жорсткість самого підшипника оцінювалася дуже приблизно, а вертикальні навантаження вважались постійно діючими.

Незначна кількість досліджень присвячена визначенню показників надійності елементів буксового вузла. Можна зазначити лише статті Б.Н. Покровського $[4,5]$, де розглядається питання про вибір нормованих показників надійності для роликового буксового вузла.

В той же час необхідно зазначити, що практично всі теоретичні дослідження в галузі визначення показників надійності буксових вузлів рухомого складу були присвячені визначенню $\gamma$-відсоткового pecypcy підшипників на підставі фундаментальних досліджень [6,7]. При цьому показники безвідмовності, а саме імовірність безвідмовної роботи, намагались обчислити складним шляхом за допомогою емпіричних коефіцієнтів, вважаючи відомим $\gamma$-відсотковий ресурс. При цьому не враховувався імовірнісний характер діючих навантажень.

Метою дослідження $\epsilon$ оцінка працездатності буксового вузла 3 урахуванням зовнішніх впливів, які можуть приймати випадкові значення під час експлуатації вагонів, й визначення імовірності безвідмовної роботи буксового вузла залежно від швидкості та режиму pyxy.

Основна частина. Буксовий підшипниковий вузол вантажного вагона $\epsilon$ механічною системою, яка взаємодіє 3 навколишнім середовищем. На нього діють певні зовнішні впливи q, які можуть приймати випадкові значення з простору Q. Стохастичну поведінку системи будемо характеризувати елементами $\mathrm{u}$, які $\epsilon$ частками відповідного простору $\mathrm{U}$, який обирається таким чином, щоб за його допомогою в рамках розрахункової схеми повністю був описаний стан системи. Властивості системи характеризуються оператором $\mathrm{L}$, який кожній реалізації елементів 3 простору впливів Q приводить у відповідність реалізацію елементів у просторі станів U.

$$
L u=q .
$$

При цьому простір якості $V$ обирається таким чином, щоб за допомогою його елементів можна було повню мірою характеризувати якість функціонування системи. При нормальній експлуатації системи піi параметри якості мають перебувати у встановлених межах протягом усього нормативного строку служби. Математично це відповідає знаходженню елементів $\mathrm{v}$ в допустимій області $\Omega$ простору якості V. Вихід траєкторії v(t) 3 допустимої області $\Omega$ відповідає відмові системи (див. рисунок).

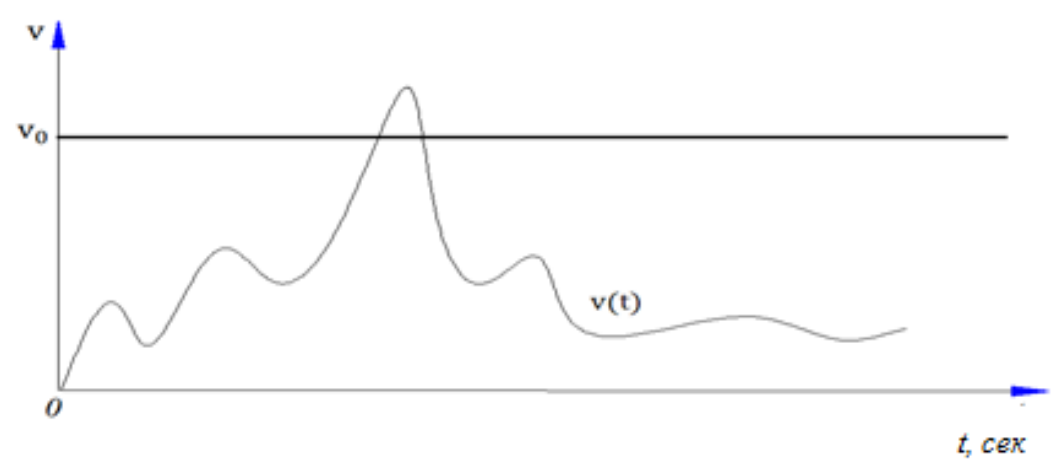

Рис. Графічна ілюстрація теорії викидів для одновимірного простору 
Основний показник надійності $P(t)$ імовірністю безвідмовної роботи на відрізку $[0, t]$, що відповідає імовірності знаходження вектора якості в допустимій області протягом цього відрізка часу,

$$
P(t)=P\{v(t) \in \Omega ; \tau \in[0, t]\} .
$$

Цей вираз не враховує розсіювання фізико-механічних властивостей матеріалів та розсіювання параметрів навантаження. За умови, що випадкові властивості системи характеризуються векторною випадковою величиною $r$, a розсіювання параметрів зовнішнього впливу $q(\mathrm{t})$ визначається вектором $\mathbf{s}$, то сумісна щільність розподілення параметрів $\mathrm{r}$ та $\mathrm{s}$ буде позначатися як $\mathrm{p}(\mathrm{r}, \mathrm{s})$. Тоді імовірність безвідмовної роботи системи обчислюється за формулою повної імовірності

$$
P(t)=\iint P(t \mid r, s) p(r, s) d r d s
$$

У вихідний момент часу випадковий процес $v(t)$ з імовірністю, яка дорівнює 1 , буде знаходитися у допустимій області $\Omega$, тобто $P(0)=1$. Викиди 3 цієї області на відрізку часу $[0, t]$ - дуже рідкі події. Математичне очікування кількості викидів випадкового процесу $v(t)$ на відрізку часу $[0, t]$ позначимо як $N(t)$. Тоді

$$
M[N(t)] \equiv \Lambda(t) \approx \int_{0}^{t} \lambda(t) d t .
$$

Це співвідношення пов'язує між собою математичне очікування кількості викидів випадкового процесу $v(t) \quad 3$ інтенсивністю відмов. У випадку, коли відповідна механічна система $\epsilon$ високонадійною (а багаторічний досвід експлуатації буксових підшипникових вузлів дає можливість це стверджувати), можливе використання пуасонівського потоку відмов. Тоді імовірність безвідмовної роботи можна обчислити за формулою$$
P(t) \approx \exp [-\Lambda(t)]
$$

Пропонується така процедура оцінки працездатності буксового вузла, яка буде складатися з таких етапів:

- побудова простору якості для найбільш відповідальних елементів буксового вузла;

$$
\text { - дослідження }
$$

характеристик випадкових процесів навантажень, що діють на буксові підшипникові вузли;

- визначення імовірності викиду випадкового процесу навантажень за простір якості; 
- обчислення характеристик

безвідмовності буксового підшипникового вузла.

Будемо розглядати підшипниковий вузол як систему, що складається 3 двох основних елементів: безпосередньо дворядний конічний підшипник та адаптер, через який на підшипник передаються усі види навантажень. Відомо, що довговічність буксових вузлів у цілому визначається, головним чином, появою раковин від утоми на поверхнях торкання кілець та роликів. Причиною виникнення цих раковин $\epsilon$ контактні напруження $\sigma(t)$, що перевищують межу міцності на стиснення. Тобто якість системи буде характеризуватися величиною максимальних контактних напружень.

Простір якості $V$ у даному випадку буде одновимірним, а область допустимих значень задана обмеженням

$$
\sigma(t)<\sigma_{c m^{y}}
$$

де $\sigma_{\text {см }}$-межа міцності на стиснення підшипникової сталі.

Величина $\sigma(t)$ залежить, у свою чергу, від величини вертикальних навантажень $Q^{e}(t)$, які діють на буксовий підшипниковий вузол. При цьому

$$
\sigma(t)=f\left[Q^{s}(t)\right]
$$

де $Q^{s}(t)$ - вертикальне навантаження, яке викликає відповідні напруження, МПа.

Тоді максимально можливим напруженням $\sigma_{\max }(t)$ можна зіставити максимально можливі вертикальні навантаження $Q_{\max }^{e}(t)$.

Вертикальні навантаження $Q^{s}(t)$, що діють на буксовий підшипниковий вузол, залежать від багатьох чинників: величини статичного навантаження, кількості осей, стану верхньої будови колії, технічного стану ходових частин і п'ятникового вузла вагона, швидкості руху тощо. На практиці останні зазначені чинники об'єднують єдиним поняттям - коефіцієнт вертикальної динаміки.

Тоді імовірність відмови БВ визначається як імовірність появи вертикальних навантажень, що викликають у його елементах напруження, яке перевищує межу міцності на стиснення, за зазначений час

$$
P(\tau)=P\left\{-Q_{\max }^{e}<Q^{e}(t)<Q_{\max }^{e} ; \tau \in[0, T]\right\}
$$

Тоді кількість випадкового процесу зміни вертикальних навантажень

$$
N(\tau)=T \int_{0}^{\infty} f\left(Q^{s}, \dot{Q}^{s}, t\right) \dot{Q}^{s} d Q^{s},
$$

де $f\left(Q^{s}, Q^{s}, t\right)$ - сумісна цільність розподілення випадкового процесу зміни вертикальних навантажень та його першої похідної.

Якщо випадковий процес $Q^{s}(t)$ - стаціонарний, то

$$
f\left(Q^{s}, \dot{Q}^{s}, t\right)=f_{1}\left[Q^{s}(t)\right] \times f_{2}\left[\dot{Q}^{s}(t)\right] .
$$

У припущенні, що процес зміни вертикальних навантажень підпорядкований нормальному закону розподілення, 


$$
\begin{gathered}
f_{1}\left[Q^{s}(t)\right]=\frac{1}{\sqrt{2 \pi} \cdot \sigma_{Q^{\varepsilon}}} \exp \left[-\frac{\left(Q^{s}-M\left[Q^{s}(t)\right]\right)^{2}}{2 \sigma_{Q^{s}}^{2}}\right], \\
f_{2}\left[\dot{Q}^{s}(t)\right]=\frac{1}{\sqrt{2 \pi} \cdot \sigma_{Q^{\varepsilon}}} \exp \left[-\frac{\left(\dot{Q}^{s}\right)^{2}}{2 \sigma_{\dot{Q}^{\varepsilon}}^{2}}\right]
\end{gathered}
$$

де $M\left[Q^{s}(t)\right]$ - математичне очікування випадкового процесу зміни вертикальних навантажень $Q^{s}(t)$;

$\sigma_{Q^{8}}^{2}$ - його дисперсія;

$\sigma_{Q^{\varepsilon}}^{2}-$ дисперсія його першої похідної;

$f_{1}\left[Q^{s}(t)\right]$ - щільність розподілення випадкового процесу зміни вертикальних навантажень;

$f_{2}\left[\dot{Q}^{s}(t)\right]-$ щільність розподілення випадкового процесу зміни похідної вертикальних навантажень.

Середне квадратичне відхилення першої похідної випадкового процесу зміни вертикальних навантажень визначається формулою

$$
\sigma_{p^{e}}=\sqrt{-\left[\frac{\ddot{K}_{p^{e}}(\tau)}{K_{p^{e}}(\tau)}\right]_{\tau=0},}
$$

де $K_{p^{e}}(\tau) \quad-\quad$ кореляційна функція випадкового процесу зміни вертикальних навантажень;

$$
\ddot{K}_{p^{a}}(\tau) \text { - друга похідна випадкового }
$$
процесу зміни вертикальних навантажень.

Остаточно формула для визначення кількості викидів матиме вигляд

$$
N(\tau)=\frac{1}{2 \pi} \sqrt{-\left[\frac{\ddot{K}_{P^{\mathrm{E}}}(\tau)}{K_{P^{\mathrm{z}}}(\tau)}\right]} \cdot \exp \left[-\frac{\left(P^{\mathrm{E}}-M\left[P^{\mathrm{E}}(t)\right]\right)^{2}}{2 \sigma_{p^{\mathrm{g}}}^{2}}\right] .
$$

Висновки 3 дослідження i перспективи, подальший розвиток у даному напрямку. При розрахунках згідно 3 [3] враховувався час перебування вагона у завантаженому та порожньому стані 3 рекомендованими швидкостями. В результаті отримані залежності, які характеризують імовірність безвідмовної роботи буксового вузла залежно від швидкості та режиму руху. Доведено, що при навіть найбільш несприятливих умовах нижня межа ймовірності безвідмовної роботи складала 0,99975 .

\section{Список літератури}

1. Корпус роликовых букс грузовых вагонов из алюминиевых сплавов [Текст] / Н. А. Буше, В. В. Копытько, В. Н. Цюренко [и др.] // Пути совершенствования конструкций буксовых узлов вагонов с подшипниками качения: труды ВНИИЖТ. - М.: Транспорт, 1982. Вып. 654. - С. 98-102.

2. Мельниченко, Ю.Д. Напряженно-деформированное состояние корпуса буксы из алюминиевого сплава: дис. ... канд. техн. наук: 05.22.07 [Текст] / Ю.Д. Мельниченко. M., 1984. $-118 \mathrm{c}$.

3. Нормы для расчета и проектирования новых и модернизируемых вагонов железных дорог МПС колеи 1520 мм (несамоходных). - М.: 1983. - 258 с. 
4. Покровский, Б.Н. К вопросу оценки надежности подшипников качения букс вагонов [Текст] / Б. Н. Покровский // Всесоюзный заочный институт инженеров транспорта: сб. науч. трудов. - М., 1979. - Вып. 101. - С. 5-8.

5. Покровский, Б.Н. К постановке вопроса об оценке надежности подшипников качения букс вагонов [Текст] / Б.Н. Покровский // Всесоюзный заочный институт инженеров транспорта: сб. науч. трудов. - М., 1978. - Вып. 97. - С. 41-49.

6. Lundberg G., Palmgren A. Dynamic Capacity of Rolling Bearings. - Acta Politechnica, Mechanical Engineering Series. - Vol. 1, №3. - 1947.

7. Lundberg G., Palmgren A. Dynamic Capacity of Rolling Bearings. - Acta Politechnica, Mechanical Engineering Series. - Vol. 2, №4. - 1952.

Ключові слова: буксовий вузол, підшипник, надійність, випадковий процес, теорія викидів, одновимірний простір, простір якості.

\section{Анотації}

Запропонована модель для визначення показників безвідмовності буксових підшипникових вузлів вантажних вагонів, особливістю якої $\epsilon$ врахування імовірнісного характеру діючих навантажень. Виконано моделювання та встановлені показники безвідмовності буксових підшипників для різних режимів руху вагонів.

Предложена модель для определения показателей безотказности буксовых подшипниковых узлов грузовых вагонов, особенностью которой является учет вероятностного характера действующих нагрузок. Выполнено моделирование и определены показатели безотказности буксовых подшипников для различных режимов движения вагона.

The model for the measurement of reliability for axle bearing freight cars, featuring a probabilistic nature of the acting loads. Modelling and reliability indicators for axle bearings are determined for various modes of motion of the car. 